\title{
Inklusi Kesadaran Pajak dalam Pembelajaran MPK Bahasa Indonesia Sebagai Upaya Penguatan Karakter Nasionalis Pada Masa Pandemi
}

\author{
Kadek Trina Des Ryantini ${ }^{1}$, Yoga Putra Semadi², Luh Putu Eka Damayanthi ${ }^{3}$ \\ 1,2 Unit MPK, Universitas Pendidikan Ganesha, Singaraja, Indonesia \\ ${ }^{3}$ Program Studi Pendidikan Teknik Informatika, Universitas Pendidikan Ganesha, Singaraja, Indonesia
}

\section{ART I CLE INFO}

Article history:

Received September 09, 2021

Revised September 10, 2021

Accepted November 20, 2021

Available online December 25, 2021

Kata Kunci:

Inklusi Kesadaran Pajak,

Pembelajaran MPK, Karakter

Nasionalis

Keywords:

Tax Awareness Inclusion, MPK

Learning, Nationalist Character

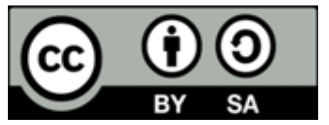

This is an open access article under the CC BY-SA license.

Copyright (ㄷ) 2021 by Author. Published by Universitas Pendidikan Ganesha.

\begin{abstract}
A B S T R A K
Penguatan nilai karater tidak hanya berkaitan dengan kesopanan dan kesantunan berperilaku tetapi juga bisa dikaitkan dengan kesadaran dan kepatuhan perpajakan. Kesadaran pajak sampai saat ini masih tergolong rendah sehingga berimbas pada rendahnya kepatuhan pajak. Penelitian ini bertujuan untuk mendeskripsikan inklusi kesadaran pajak dalam pembelajaran MPK Bahasa Indonesia sebagai penguatan karakter nasionalis sehingga mahasiswa memiliki sikap positif terhadap bahasa Indonesia dan kesadaran pajak sebagai wujud penunjang karakter nasionalis (cinta tanah air). Penelitian ini merupakan penelitian deskriptif dengan pendekatan kualitiatif. Subjek penelitian ini adalah mahasiswa rombel MPK Undiksha sebanyak 130 orang. Penelitian ini menggunakan metode dokumentasi dengan instrumen penelitian berupa pedoman dokumentasi dan kuesioner. Data penelitian dianalisis dengan metode deskriptif kualitatif, yang meliputi pengumpulan data, reduksi data, penyajian data, dan verifikasi data. Hasil penelitian ini menunjukkan bahwa masih ada mahasiswa yang belum memiliki pengetahuan tentang definisi pajak; wajib pajak; dampak tidak membayar pajak; sanksi dan manfaat pajak sehingga berimbas pada kesadaran pajak. Penelitian inklusi kesadaran pajak ini dapat menguatkan karakter nasionalis mahasiswa, yaitu memupuk kesadaran pajak dan sikap positif sebagai penutur bahasa Indonesia. Hal ini membuktikan bahwa inklusi kesadaran pajak dalam pembelajaran MPK di perguruan tinggi, penting dan harus dilanjutkan sehingga dapat memberikan penguatan nilai-nilai karakter bangsa.
\end{abstract}

\section{A B S T RA C T}

The character strengthening values is not only related to politeness but can also be associated with awareness and tax compliance. Tax awareness is still relatively low so that it is impacted on low tax compliance. This study aims to describe the inclusion of tax awareness in learning Indonesian (MPK) as a strengthening the nationalist character, so that, the students have a positive attitude towards the Indonesian and tax awareness as a form of supporting the nationalist character (love the country). This research is a descriptive research with a qualitative approach. The subjects of this study were 130 students of Undiksha (MPK study group). This study used the documentation method with research instruments in the form of documentation guidelines and questionnaires. The research data were analyzed using descriptive qualitative methods, which included data collection, data reduction, data presentation, and data verification. The results of this study indicated that some students did not know the definition of tax, taxpayer, the impact of not paying taxes, tax penalty and tax benefits that impacted on tax awareness. This tax awareness inclusion research could strengthen the nationalist character of the students, fostering tax awareness and a positive attitude as Indonesian speakers. This proves that the inclusion of tax awareness in MPK learning in university is important and must be continued, so that it can strengthen the national character values.

\section{PENDAHULUAN}

Manusia sebagai makhluk individu mempunyai ciri masing-masing, hal ini bisa ditunjukkan dari karakter yang dimiliki oleh masing-masing individu. Karakter adalah ciri khas seseorang yang 
mengandung nilai, kemampuan, kapasitas moral, dan ketegaran dalam menghadapi kesulitan dan tantangan yang dapat dibentuk melalui pengaruh lingkungan sosial (Andarwati, 2017; Imam, 2018; Kuswara \& Sumayana, 2020; Marjanto, 2019; Navisah, 2017; Pratama, 2016; Sukirman \& Minarwati, 2020). Karakter hakikatnya adalah watak, tabiat, akhlak, atau kepribadian seseorang yang terbentuk dari hasil internalisasi berbagai kebajikan (virtues) yang diyakini dan digunakan sebagai landasan untuk cara pandang, berpikir, bersikap, dan bertindak (Adibatin, 2016). Karakter tidak hanya tumbuh dan berkembang pada setiap individu, tetapi juga pada organisasi atau institusi pendidikan (Ansori, 2020a). Oleh karena itu, dapat dikatakan bahwa karakter adalah watak seseorang, kepribadian, atau akhlak yang diperoleh dari internalisasi dengan lingkungannya, baik di masyakarat maupun di lingkungan pendidikan. Adanya karakter akan berdampak positif terhadap pembentukan seseorang, karena sesearang yang professional dalam bidangnya tidak hanya didukung oleh tingkat pengetahuannya tetapi juga harus didukung dengan karakter yang baik (Hariti et al., 2020). Untuk memupuk karakter yang baik pada peserta didik maka dilakukan berbagai cara salah satunya adalah penerapan pendidikan karakter. Pendidikan karakter merupakan usaha mengembangkan karakter sehingga mampu mencapai nila-nilai karakter yang diinginkan oleh bangsa (Dewi et al., 2019). Melalui pendidikan karakter diharapkan lahir generasi bangsa yang memiliki karakter tangguh, hebat, dan sesuai dengan nilai-nilai luhur Pancasila (Hermawan, 2021). Adanya pendidikan karakter akan membentuk bangsa yang tangguh, kompetitif, berakhlak mulia, bermoral, bertoleran, berjiwa patriotik, berkembang dinamis (afektif, kognitif, dan psikomotor), berorientasi ilmu pengetahuan dan teknologi, inovatif, yang semuanya dijiwai oleh iman dan takwa kepada Tuhan Yang Maha Esa berdasarkan Pancasila dan diwujudkan dalam kehidupan sehari-hari dengan sepenuh hati (Munif et al., 2021; Priyambodo, 2017; Suheli, 2018; Sujatmiko et al., 2019).

Implementasi pendidikan karakter di Indonesia sudah banyak dilakukan. Hal ini dibuktikan dengan penelitian-penelitian yang sudah dilakukan. Beberapa hasil penelitian menyatakan bahwa penggunaan metode pembelajaran sosiodrama dalam pembelajaran di sekolah secara tidak langsung akan membentuk karakter peserta didik yang menjunjung nilai-nilai moral yang baik dan benar (Faqih, 2019). Penelitian yang menyatakan bahwa proses penguatan karakter nasionalisme peserta didik di wilayah perbatasan dapat dilakukan melalui program pembiasaan pelaksanaan upacara bendera, penggunaan bahasa Indonesia yang baik dan benar, kunjungan ke wilayah perbatasan, yel-yel kebangsaan, menyanyikan lagu kebangsaan saat memulai dan mengakhiri pembelajaran hingga keteladanan dari seorang guru di lingkungan SMPN Silawan. Penelitian yang menyatakan bahwa kegiatan membaca buku cerita atau mendongeng memiliki banyak manfaat dan nilai karakter (Rosid, 2021). Penelitian menyatakan bahwa implementasi pendidikan karakter telah meningkatkan perilaku siswa, seperti mengurangi buly, konflik dan kekerasan (Ansori, 2020b). Penelitian yang menyatakan bahwa pendidikan karakter berpengaruh terhadap karakter siswa, yaitu terjadinya tumbuh dan berkembangnya karakter religius, patuh, disiplin, komunikatif dan tanggung jawab pada siswa (Amin et al., 2018). Jadi, pendidikan karakter memberikan dampak postif terhadap pembentukan karakter peserta didik pada jenjang sekolah dasar, sekolah menengah dan perguruan tinggi.

Namun, saat ini implementsi pendidikan karakter belum bisa dikatakan optimal dilakukan. Hal ini ditunjukkan bahwa masih banyak terjadi korupsi, perang suku, tawuran serta keributan antarwarga yang mencerminkan kurangnya karakter masyarakat (Abdullah et al., 2015). Selain itu, kondisi karakter yang terjadi pada peserta didik, yaitu kurangnya kemandirian peserta didik, cepatnya putus asa, serta kurangnya inisiatif dari siswa sehingga menyebabkan proses pembelajaran tidak hidup dan kurang aktif (Labudasari \& Rochmah, 2019). Aktivitas keseharian peserta didik menujukkan sikap kurang sopan terhadap guru maupun kepala sekolah (Cahyono et al., 2018). Untuk kondisi lebih besar, rendahnya nilai karakter ditunjukkan dengan kesadaran pajak yang sampai saat ini masih tergolong rendah. Hal ini bisa dilihat dari data realisasi penyampaian SPT Tahunan secara keseluruhan per 1 Mei 2020 sesuai data Direktorat Jenderal Pajak (DJP) hanya 10,97 juta wajib pajak (WP). Ini lebih rendah daripada capaian pada tanggal yang sama tahu nlalu yang mencapai 12,11 juta wajib pajak yang melaporkan SPT Tahunan. Selain itu, rasio kepatuhan formal pun turun dari 66 persen pada 1 Mei tahun lalu menjadi 57,7 persen tahun ini. Hal tersebut menunjukkan bahwa terjadi kontraksi sebesar 9,4 persen secara tahunan (year on year/yoy) dalam penyampaian SPT Tahunan secara keseluruhan (Pajakonline, 2020). Data tersebut menunjukkan bahwa kesadaran pajak masyarakat masih tergolong rendah sehingga berimbas pada rendahnya kepatuhan pajak. Hal ini menunjukkan karakter nasionalis dalam perpajakan masih rendah. Tentunya, jika hal ini dibiarkan tidak berdampak baik terhadap kondisi bangsa nantinya. Oleh sebab itulah, kondisi ini harus dicarikan solusi yang tepat agar masalah yang berkaitan dengan karakter nasionalis khususnya kesadaran pajak dapat dikurangi. Pemerintah saat ini terus menggalakkan peningkatan pendidikan karakter kepada peserta didik. Mengingat pentingnya menguatkan pendidikan karakter ini di era 4.0 maka perlu diadakan kerja sama antara berbagai pihak (Sujatmiko et al., 2019). Salah satu wujud nyata keseriusan pemerintah dalam upaya peningkatan karakter, yaitu melalui inklusi kesadaran pajak. Inklusi 
kesadaran pajak adalah usaha yang dilakukan oleh Direktorat Jenderal Pajak bersama dengan kementerian yang membidangi pendidikan untuk meningkatkan kesadaran perpajakan peserta didik, guru, dan dosen yang dilakukan melalui integrasi materi kesadaran pajak dalam kurikulum, pembelajaran, dan perbukuan (DJP, 2016). Melalui inklusi kesadaran pajak, diharapkan pada tahun 2045 terbentuk generasi emas yang sadar pajak. Generasi emas adalah sebuah generasi di mana negara Indonesia pada tahun 2045 genap berusia 100 tahun atau satu abad dan mendapatkan bonus demografi berupa melonjaknya usia produktif sebesar 70\% dengan range usia mulai 15 tahun hingga 64 tahun (Hermawan, 2021). Dengan demikian, inklusi kesadaran pajak dalam pembelajaran dapat dijadikan sebagai penguatan pendidikan karakter saat ini.

Pembelajaran pada dasarnya adalah kegiatan aktif membangun makna dalam diri siswa yang kelak membentuk pribadi yang berkarakter dan unggul (Munirah et al., 2021). Hal ini sama dengan tujuan inklusi kesadaran pajak, yaitu membentuk kesadaran pajak. Peningkatan kesadaran pajak ini dapat dilakukan melalui kegiatan edukasi dan sosialisasi (Sukowidyanti et al., 2019). Sosialisasi perpajakan merupakan upaya pemerintah untuk memberikan pengetahuan dan pemahaman mengenai peraturan dan ketentuan perpajakan yang berlaku kepada masyarakat (Vionita \& Kristanto, 2018). Tingkat moral pajak menentukan tingkat kepatuhan seseorang terhadap peraturan perpajakan (Ruky et al., 2018). Semakin tinggi tingkat kesadaran wajib pajak maka pemahaman dan pelaksanaan kewajiban perpajakan semakin baik sehingga dapat meningkatkan kemauan membayar pajak (As'ari \& Erawati, 2018; Dharma, Ida Bagus Alit Surya Astika, 2021; Mahendra \& Budhiarta, 2020; Marjanto, 2019; Negara \& Dewi, 2019; Permatasari \& M, 2019; Supriatna, 2020; Yuliadi, 2018). Selanjutnya, kesadaran wajib pajak merupakan hal yang penting dalam perpajakan untuk meningkatkan kepatuhan wajib pajak (Antari \& Supadmi, 2019; Kartikasari \& Yadnyana, 2020). Dapat dikatakan bahwa inklusi kesadaran pajak menjadi salah satu cara efektif menumbuhkan budaya taat pajak bagi para calon wajib pajak dan masyarakat yang sudah menjadi wajib pajak. Beberapa penelitian yang relevan terkait inklusi pajak juga pernah dilakukan, antara lain penelitian yang menyatakan bahwa pemahaman perpajakan mahasiswa masih kurang tentang pengertian pajak, fungsi pajak, regulasi dan mekanisme pembayaran pajak, jenis-jenis pajak, hingga pemberitaan tentang penyelewengan pajak di Indonesia (Dianastiti, 2019). Penelitian lainnya menunjukkan bahwa generasi muda (mahasiswa) di D.I. Yogyakarta dan Surabaya masih banyak yang kurang menyadari betapa penting peran pajak dalam pembangunan Indonesia karena mahasiswa kurang memahami pengertian tentang pajak (Jaya, 2019). Berdasarkan hasil penelitian sejenis tersebut diketahui bahwa inklusi kesadaran pajak masih difokuskan pada persepsi mahasiswa terhadap pajak dan belum terintegrasi dalam pembelajaran. Oleh karena itulah, perlu dilakukan sebuah penelitian yang berkaitan dengan inklusi kesadaran pajak.

Penelitian inklusi kesadaran pajak ini dilakukan di tingkat perguruan tinggi dan diintegrasikan dalam pembelajaran MPK Bahasa Indonesia untuk memperkuat karakater nasionalis. Penelitian inklusi kesadaran pajak dalam pembelajaran MPK Bahasa Indonesia, tidak hanya fokus pada persepsi dan pemahaman mahasiswa terhadap pajak tetapi juga difokuskan dengan penguatan karakter nasionalis. Artinya, selain memiliki pemahaman dan kesadaran perpajakan yang berimbas pada kepatuhan perpajakan, mahasiswa juga memiliki keterampilan berbahasa Indonesia yang menunjang sika cinta tanah air (nasionalis). Cinta tanah air dapat diartikan juga sebagai cara berpikir, bersikap, dan berbuat yang menunjukan kesetiaan, kepedulian, dan penghargaan yang tinggi terhadap bahasa, lingkungan fisik, sosial, budaya, ekonomi, dan politik bangsa (H, 2017). Selanjutnya, rasa cinta terhadap bangsa dapat disebut juga sebagai nasionalisme. Oleh karena itulah, penelitian inklusi pajak dalam pembelajaran MPK Bahasa Indonesia sebagai penguatan karakter nasionalis, urgen dan layak dilakukan. Penelitian ini bertujuan untuk mendeskripsikan inklusi kesadaran pajak dalam pembelajaran MPK Bahasa Indonesia sebagai penguatan karakter nasionalis sehingga mahasiswa memiliki sikap positif terhadap bahasa Indonesia dan kesadaran pajak sebagai wujud penunjang karakter nasionalis (cinta tanah air). Hasil penelitian ini dapat memberikan "nuansa baru" dalam pembelajaran MPK sebagai penguatan pendidikan karakter.

\section{METODE}

Penelitian ini merupakan penelitian deskriptif dengan pendekatan kualitiatif. Penelitian deskriptif kualitatif adalah penelitian yang berusaha menggambarkan sesuatu dengan menggunakan katakata (Arikunto, 2002). Langkah penelitian ini diawali dengan melakukan identifikasi masalah, pembatasan masalah, dan fokus penelitian, yakni penelitian hanya berkaitan dengan inklusi kesadaran pajak melalui pembelajaran MPK Bahasa Indonesia sebagai penguatan karakter cinta tanah air (nasionalis). Langkah berikutnya adalah pengumpulan data yang dilakukan dengan pencatatan dokumen dan kuesioer. Setelah data terkumpul, dilakukan pemeriksaan data, yakni memilih data yang diperlukan dan yang kurang penting disisihkan, terutama data kuesioner yang tidak relevan dengan penelitian ini. Lalu, pemunculan 
teori dilakukan untuk membedah masalah penelitian yang dikuatkan dengan pendapat ahli yang relevan dengan penelitian ini. Setelah itu, bersama pembimbing dan tim peneliti melakukan penarikan simpulan, kemudian diakhiri dengan penyusunan laporan akhir.

Penelitian ini berlokasi di Universitas Pendidikan Ganesha. Subjek penelitian ini adalah mahasiswa rombel MPK 1, 2, 3, 13, dan 14, dengan umur 18-20 th, jumlah perempuan sebanyak 86 orang dan laki-laki 44 orang. Metode pengumpulan data yang digunakan dalam penelitian ini adalah metode pencatatan dokumen atau dokumentasi. Menurut Sugiyono (2006), dokumen bisa berbentuk tulisan, gambar,atau karya-karya monumental dari seseorang. Dalam penelitian ini, metode dokumentasi digunakan untuk mendapatkan data berupa inklusi kesadaran pajak dalam pembelajaran MPK Bahasa Indonesia. Data akan diperoleh melalui pembelajaran MPK Bahasa Indonesia dengan mendokumentasikan tugas-tugas mahasiswa terkait dengan inklusi kesadaran pajak, selama 13 kali pertemuan secara online, baik melalui schoology dan e-learning Undiksha. Selanjutnya, penelitian ini juga menggunakan instrumen kuesioner. Bentuk kuesioner yang digunakan dalam menjaring data, yakni kombinasi antara kuesioner tertutup dan kuesioner terbuka. Pada tabel 1 dapat dilihat kisi-kisi instrumen kuesioner inklusi kesadaran pajak. Selanjutnya, data dianlisis dengan metode deskriptif kualitatif, yang meliputi pengumpulan data, reduksi data, penyajian data, dan verifikasi data.

Tabel 1. Inklusi Kesadaran Pajak dalam Pembelajaran MPK Bahasa Indonesia

\begin{tabular}{|c|c|c|}
\hline Indikator & Butir Pertanyaan & Respons \\
\hline $\begin{array}{l}\text { Pengetahuan Definisi } \\
\text { Pajak }\end{array}$ & $\begin{array}{l}\text { Apakah sebelum mengikuti perkuliahan inklusi kesadaran } \\
\text { pajak dalam pembelajaran bahasa Indonesia, Anda sudah } \\
\text { tahu definisi pajak? }\end{array}$ & Ya/Tidak \\
\hline $\begin{array}{l}\text { Pengetahuan Definisi } \\
\text { Wajib Pajak }\end{array}$ & Apakah Anda tahu definisi Wajib Pajak? & Ya/Tidak \\
\hline Kontribusi Pajak & $\begin{array}{l}\text { Apakah Anda tahu bahwa jika tidak membayar pajak dapat } \\
\text { merugikan negara? }\end{array}$ & Ya/Tidak \\
\hline Sanksi Pajak & Apakah Anda tahu sanksi pajak? & Ya/Tidak \\
\hline Manfaat Pajak & Apakah Anda tahu bahwa pajak memiliki manfaat? & Ya/Tidak \\
\hline $\begin{array}{l}\text { Pemahaman Inklusi } \\
\text { Kesadaran Pajak }\end{array}$ & $\begin{array}{l}\text { Apakah Anda paham tentang inklusi kesadaran pajak dalam } \\
\text { pembelajaran? }\end{array}$ & Argumen \\
\hline $\begin{array}{l}\text { Pelaksanaan Inklusi } \\
\text { Kesadaran Pajak }\end{array}$ & $\begin{array}{l}\text { Bagaimana pendapat Anda tentang inklusi kesadaran pajak } \\
\text { dalam pembelajaran MPK Bahasa Indonesia? }\end{array}$ & Argumen \\
\hline Penguatan Karakter & $\begin{array}{l}\text { Menurut Anda, apakah inklusi kesadaran pajak dalam } \\
\text { pembelajaran MPK Bahasa Indonesia dapat menguatkan } \\
\text { karakter nasionalis }\end{array}$ & Argumen \\
\hline Kesadaran Pajak & $\begin{array}{l}\text { Setelah mengikuti perkuliahan inklusi kesadaran pajak, } \\
\text { apakah Anda mulai menyadari bahwa pajak itu penting? }\end{array}$ & Argumen \\
\hline $\begin{array}{l}\text { Tindak Lanjut Inklusi } \\
\text { Kesadaran Pajak di } \\
\text { Perguruan Tinggi }\end{array}$ & $\begin{array}{l}\text { Bagaimana saran Anda terkait inklusi kesadaran pajak di } \\
\text { perguruan tinggi? }\end{array}$ & Argumen \\
\hline
\end{tabular}

\section{HASIL DAN PEMBAHASAN}

Hasil

Penguatan nilai karater tidak hanya berkaitan dengan kesopanan dan kesantunan berperilaku tetapi juga bisa dikaitkan dengan kesadaran dan kepatuhan perpajakan. Kesadaran dan kepatuhan perpajakan ini akan muncul apabila calon wajib pajak dan wajib pajak memiliki pengetahuan tentang perpajakan. Berkaitan dengan hal itu, dari hasil penelitian terlihat bahwa masih ada mahasiswa yang belum mengetahui definisi pajak sebesar 17,70\%; wajib pajak 20\%; dampak jika tidak membayar pajak 7,70\%; sanksi pajak 30\%; dan manfaat pajak 5,4\%. Ketidaktahuan mahasiswa tentang hal itu berdampak pada tingkat kesadaran pajak. Kesadaran wajib pajak merupakan hal yang penting dalam perpajakan untuk meningkatkan kepatuhan wajib pajak (Antari \& Supadmi, 2019; Kartikasari \& Yadnyana, 2020). Peningkatan kesadaran pajak ini dapat dilakukan melalui kegiatan edukasi dan sosialisasi (Sukowidyanti et al., 2019). Sosialisasi perpajakan merupakan upaya pemerintah untuk memberikan pengetahuan dan pemahaman mengenai peraturan dan ketentuan perpajakan yang berlaku kepada masyarakat (Vionita \& Kristanto, 2018). Tingkat moral pajak menentukan tingkat kepatuhan seseorang terhadap peraturan perpajakan (Ruky et al., 2018). Semakin tinggi tingkat kesadaran wajib pajak maka pemahaman dan pelaksanaan kewajiban perpajakan semakin baik sehingga dapat meningkatkan kemauan membayar 
pajak (As'ari \& Erawati, 2018; Dharma, Ida Bagus Alit Surya Astika, 2021; Mahendra \& Budhiarta, 2020; Marjanto, 2019; Negara \& Dewi, 2019; Permatasari \& M, 2019; Supriatna, 2020; Yuliadi, 2018). Jadi, pengetahuan dan pemahaman pajak akan menumbuhkan kesadaran dan kepatuhan perpajakan dalam diri mahasiswa sebagai calon wajib pajak. Adanya kesadaran perpajakan tersebut akan memberi pengaruh dalam meningkatkan penerimaan pajak (Herlina, 2020). Untuk itulah, pengetahuan perpajakan diberikan melalui inklusi kesadaran pajak dalam pembelajaran MPK Bahasa Indonesia sebagai bentuk pembinaan dan penguatan karakter. Inklusi kesadaran pajak ini dilakukan selama 13 kali pertemuan dalam satu semester. Dengan penerapan hal ini tentunya akan sangat membantu mahasiswa untuk mengembangkan kesadaran pajak.

Temuan yang lain dari penelitian ini adalah hasil penelitian menunjukan bahwa pada setiap pertemuan pembelajaran MPK Bahasa Indonesia, bahan bacaan dan tugas yang diberikan selalu bertema pajak. Hal ini penting untuk memberikan pengetahuan umum perpajakan kepada mahasiswa. Melalui kegiatan membaca teks bertema pajak, mahasiswa mendapatkan informasi umum tentang definisi pajak; wajib pajak; dampak jika tidak membaya pajak; sanksi pajak; manfaat pajak; dan masalah perpajakan di Indonesia. Penyisipan informasi perpajakan dalam pembelajaran MPK Bahasa Indonesia berimbas pada tumbuhnya kesadaran mahasiswa tentang pentingnya konstribusi pajak bagi negara. Adanya kesadaran warga negara dalam membayar pajak akan memperlancar roda pemerintahan, lancarnya roda pemerintahan akan melancarkan pula tercapainya keseluruhan cita-cita rakyat yang hidup dalam negara yang adil dan makmur (Nugroho \& Kusdarini, 2016). Selama mengikuti kegiatan inklusi pajak dalam pembelajaran MPK Bahasa Indonesia, mahasiswa juga mendapatkan penguatan nilai karakter. Nilai karakter yang dikuatkan adalah karakter nasionalis. Nilai nasionalis dikuatkan melalui pemberian materi, bahan bacaan, dan tugas-tugas keterampilan berbahasa Indonesia bertema pajak. Melalui kegiatan menyimak; membaca; berbicara; dan menulis dengan tema perpajakan, mahasiswa memiliki pengetahuan umum tentang perpajakan di Indonesia. Kebiasaan membaca dan menulis dengan tema pajak akan menumbuhkan kesadaran bahwa konstribusi pajak dalam pembangunan nasional sangat besar. Kesadaran pajak sangat berkaitan dengan nilai karakter nasionalis. Nasionalisme yakni sikap dan tindakan yang menempatkan kepentingan bangsa dan negara di atas kepentingan pribadi atau individu dan golongan (Bidaya \& Dari, 2020). Sikap yang dikembangkan dalam nilai nasionalis, yaitu apresiasi budaya sendiri, menjaga kekayaan budaya bangsa, rela berkorban, unggul dan berprestasi, cinta tanah air, menjaga lingkungan dan taat hukum, disiplin, menghormati keragaman budaya, suku dan agama (Andarwati, 2017). Nilai karakter nasionalis merupakan cara berpikir, bersikap, dan berbuat yang menunjukkan kesetiaan, kepedulian, dan penghargaan yang tinggi terhadap bahasa, lingkungan fisik, sosial, budaya, ekonomi, dan politik bangsa, menempatkan kepentingan bangsa dan negara di atas kepentingan diri dan kelompoknya (Nasiruddin, 2018). Melalui inklusi kesadaran pajak, karakter nasionalis dapat dibina dan dikuatkan sehingga mahasiswa bisa memupuk rasa cinta dan bangga menggunakan bahasa Indonesia, sekaligus menyadari pentingnya konstribusi pajak terhadap bangsa dan negara Indonesia. Artinya, mahasiswa tidak hanya mendapatkan keterampilan berbahasa Indonesia tetapi juga menumbuhkan kesadaran pajak sebagai calon wajib pajak.

\section{SIMPULAN}

Inklusi kesadaran pajak dalam pembelajaran Bahasa Indonesia dapat menguatkan karakter nasionalis mahasiswa. Melalui inklusi kesadaran pajak dalam pembelajaran MPK Bahasa Indonesia, mahasiswa dapat memupuk rasa cinta dan bangga terhadap bahasa Indonesia sekaligus menumbuhkan kesadaran pajak sebagai calon wajib pajak. Selanjutnya, dalam ragka replikasi, jangkauan penelitian ini dapat diperluas oleh peneliti lainnya, dengan latar, subjek, sumber data, dan masalah yang lebih luas. Dengan demikian, wawasan penelitian semakin luas dan lebih mantap sehingga dapat meningkatkan kepercayaan terhadap hasil penelitian ini, khususnya dalam pembelajaran MPK.

\section{UcapanTerima Kasih}

Terima kasih kami ucapkan kepada Universitas Pendidikan Ganesha sebagai penyandang dana penelitian bagi dosen pemula melalui DIPA BLU Universitas Pendidikan Ganesha dengan Kontrak Penelitian Nomor: 195/UN48.16/LT/2021. Selanjutnya, terima kasih kami sampaikan pula kepada Dr.I Putu Mas Dewantara, S.Pd.,M.Pd, sebagai pembimbing yang telah memberikan konstribusi berupa arahan, masukan, dan motivasi sehingga penelitian ini bisa selesai tepat waktu. 


\section{DAFTAR PUSTAKA}

Abdullah, B., Radiansyah, R., \& Akbar, A. (2015). Pendidikan Karakter Di Madrasah Aliyah Negeri (Man) 2 Banjarmasin. Inferensi, 9(2), 537. https://doi.org/10.18326/infsl3.v9i2.537-560.

Adibatin, A. (2016). Pendidikan Karakter Bangsa Berbasis Strategi Pembelajaran PAKEM Melalui Permainan Cincin di Jempol Tangan (Karya Inovasi Pembelajaran Sekolah Dasar). Scholaria: Jurnal Pendidikan Dan Kebudayaan, 6(1), 1. https://doi.org/10.24246/j.scholaria.2016.v6.i1.p118.

Amin, M., Syahnaidi, Q., \& Baroroh, R. U. (2018). Integrasi Pendidikan Karakter dalam Pembelajaran Bahasa Arab di Sekolah Muhammadiyah. Journal of Arabic Studies, 3(2), 181-195. https://doi.org/10.24865/ajas.v3i2.97.

Andarwati, M. (2017). Menguatkan Karakter Bhineka Tunggal Ika Melalui Pembelajaran Sejarah di Kelas. $\begin{array}{llll}\text { Jurnal Sains } & \text { Psikologi, } & 11(2), & 172-179 .\end{array}$ https://doi.org/http://dx.doi.org/10.17977/um020v11i22017p174.

Ansori, Y. Z. (2020a). Pembinaan Karakter Siswa Melalui Pembelajaran Terpadu Di Sekolah Dasar. Jurnal $\begin{array}{llll}\text { Educatio FKIP } & \text { UNMA, }\end{array}$ https://ejournal.unma.ac.id/index.php/educatio/article/download/308/202/.

Ansori, Y. Z. (2020b). Penguatan karakter disiplin siswa melalui peranan guru di sekolah dasar. Jurnal Elementaria Edukasia, 3(1), 126-135. https://ejournal.unma.ac.id/index.php/educatio/article/download/308/202/.

Antari, N. L. P. Y., \& Supadmi, N. L. (2019). Pengaruh Penerapan Sistem Administrasi Perpajakan Modern, Kualitas Pelayanan dan Kesadaran Wajib Pajak pada Kepatuhan WPOP. E-Jurnal Akuntansi, 26(1), 221 - 250. https://doi.org/https://doi.org/10.24843/EJA.2019.v26.i01.p09.

Arikunto, S. (2002). Prosedur Penelitian: Suatu Pendekatan Praktik (Edisi Revisi). Rineka Cipta.

As'ari, N. G., \& Erawati, T. (2018). Pengaruh Pemahaman Peraturan Perpajakan, Kualitas Pelayanan, Kesadaran Wajib Pajak dan Sanksi Pajak Terhadap Kepatuhan Wajib Pajak Orang Pribadi (Studi Empiris pada Wajib Pajak Orang Pribadi Kecamatan Rongkop Akuntansi Dewantara. 2(1), 46-55. https://doi.org/10.29230/ad.v2i1.2221.

Bidaya, Z., \& Dari, S. M. (2020). Revolusi Mental Melalui Penguatan Pendidikan Karakter untuk Siswa Berkebutuhan Khusus di Kota Mataram. CIVICUS : Pendidikan-Penelitian-Pengabdian Pendidikan Pancasila Dan Kewarganegaraan, 8(2), 51. https://doi.org/10.31764/civicus.v8i2.2861.

Cahyono, B., Tsani, D. F., \& Rahma, A. (2018). Pengembangan Buku Saku Matematika Berbasis Karakter pada Materi Trigonometri. Jurnal Phenomenon, 08(2), 185-199. http://dx.doi.org/10.21580/phen.2018.8.2.2929.

Dewi, A. K. T., Degeng, I. N. S., \& Hadi, S. (2019). Implementasi Pendidikan Nilai Karakter di Sekolah Dasar Melalui Budaya Sekolah. Jurnal Pendidikan: Teori, Penelitian, Dan Pengembangan, 4(2), 247-255. https://doi.org/https://doi.org/10.17977/jptpp.v4i2.12011.

Dharma, Ida Bagus Alit Surya Astika, I. B. P. (2021). Kondisi Keuangan, Kualitas Pelayanan, Sanksi Perpajakan, Kesadaran dan Kepatuhan Wajib Pajak Kendaraan Bermotor. E-Jurnal Akuntansi, 31(7). https://doi.org/https://doi.org/10.24843/EJA.2021.v31.i07.p01.

Dianastiti, F. E. (2019). Urgensi Inklusi Pajak pada Mata Kuliah Umum di Perguruan Tinggi: Studi Kasus Persepsi dan Pemahaman Perpajakan MahasiswaUniversitasTidar. https://doi.org/https://jurnal.untidar.ac.id/index.php/publicadminis/article/view/2394.

DJP. (2016). Inklusi Kesadaran Pajak dalam Pendidikan.

Faqih, F. I. (2019). Pembentukan Karakter Peserta Didik Melalui Sosiodrama. Jurnal Pendidikan Bahasa Dan Sastra Indonesia, 4 4(1), https://doi.org/https://doi.org/10.21107/metalingua.v4i1.6123.

H, A. W. (2017). Penerapan Media Video Jejak Petualang Trans 7 dalam Pembelajaran Pengetahuan Sosial (IPS) untuk Meningkatkan Karakter Cinta Tanah Air pada Siswa Kelas VIII G SMP Negeri 3 Lembang. International Journal Pedagogy of Social Studies (JAN 2017), 1(1). https://doi.org/https://doi.org/10.17509/ijposs.v1i1.2086.

Hariti, T., Rejeki, S., \& Ernawati. (2020). Strengthening soft skills as the character of student nurses through the preceptorship management model. Enfermeria Clinica, 30(2019), 64-68. https://doi.org/10.1016/j.enfcli.2019.11.022.

Herlina, V. (2020). Pengaruh Sanksi, Kesadaran Perpajakan dan Kualitas Pelayanan Terhadap Kepatuhan Wajib Pajak Bumi dan Bangunan di Kabupaten Kerinci. Jurnal Benefita, 5(2), 252-263. https://doi.org/Https://doi.org/10.22216/jbe.v5i2.5168.

Hermawan, Y. D. (2021). Manajemen Pembelajaran dalam Meningkatkan Pendidikan Karakter Guna Mewujudkan Generasi Emas Indonesia Siswa MTS Tahfidz Yanbu'ul Qur'an Kudus, Indonesia. DAYAH: Journal of Islamic Education, 4(2), 176-191. 
https://doi.org/http://dx.doi.org/10.22373/jie.v4i2.8307.

Imam, S. (2018). Nilai-nilai Pendidikan Karakter dalam Alat Evaluasi Bahasa Indonesia. Jurnal Pendidikan Karakter, 8(1), 74-83. https://doi.org/https://doi.org/10.21831/jpk.v8i1.21676.

Jaya, I. M. L. M. (2019). Realita Kesadaran Pajak di Kalangan Generasi Muda (Mahasiswa) Yogyakarta dan Surabaya. Jurnal Ilmiah Akuntansi, 4(2), 161-183.

Kartikasari, N. L. G. S., \& Yadnyana, I. K. (2020). Pengetahuan Perpajakan, Sanksi Pajak Kesadaran Wajib Pajak dan Kepatuhan WPOP Sektor UMKM. E-Jurnal Akuntansi, 31(4), 925-936. https://doi.org/https://doi.org/10.24843/EJA.2021.v31.i04.p10.

Kuswara, \& Sumayana, Y. (2020). Apresiasi Cerita Rakyat sebagai Upaya Memperkuat Karakter Siswa dalam Menghadapi Revolusi Industri 4.0. Jurnal Basicedu, 5(1), 317-326. https://doi.org/https://doi.org/10.31004/basicedu.v5i1.678.

Labudasari, E., \& Rochmah, E. (2019). Pengaruh gerakan literasi sekolah terhadap karakter mandiri siswa di SDN Kanggraksan Cirebon. Premiere Educandum : Jurnal Pendidikan Dasar Dan Pembelajaran, 9(1), 57. https://doi.org/10.25273/pe.v9i1.4254.

Mahendra, I. P. A. J., \& Budhiarta, K. (2020). Pengaruh Penerapan E-Filling Perpajakan, Kualitas Pelayanan, Kesadaran Wajib Pajak, dan Sanksi Perpajakan pada Kepatuhan WPOP. E-Jurnal Akuntansi, 30(5), 1183 - 1195. https://doi.org/https://doi.org/10.24843/EJA.2020.v30.i05.p09.

Marjanto, D. K. (2019). Pewarisan Nilai Budaya Melalui Pranata Pendidikan Adat dalam Rangka Mendukung Program Penguatan Pendidikan Karakter (PPK). Jurnal Penelitian Sejarah Dan Budaya (Patanjala), 11(2), 249 - 263. https://doi.org/https://doi.org/10.30959/patanjala.v11i2.506.

Munif, M., Rosi, F., \& Yusrohlana, S. (2021). Strategi Guru dalam Membentuk Karakter Siswa melalui Nilainilai Kejujuran. Jurnal Pendidikan Dasar (Fondatia), 5(2), 163 - 179. https://doi.org/https://doi.org/10.36088/fondatia.v5i2.1409.

Munirah, Mudaksir, \& Juanda. (2021). Perbandingan Pemikiran Tokoh Dalam Novel Dahlan dan Novel Penakluk Badai Serta Relevansinya Terhadap Pembelajaran Sastra Berbasis Karakter di SMA. Jurnal Kependidikan: Jurnal Hasil Penelitian Dan Kajian Kepustakaan Di Bidang Pendidikan, Pengajaran Dan Pembelajaran, 7(3), 631-640. https://doi.org/https://ejournal.undikma.ac.id/index.php/jurnalkependidikan/index.

Nasiruddin. (2018). Pembentukan Karakter Anak melalui Keteladanan Orang Tua. Jurnal Kependidikan, 6(2), 232-333. https://doi.org/https://doi.org/10.24090/jk.v6i2.1933.

Navisah, I. (2017). Model Pengembangan Karakter dalam Keluarga. Jurnal Psikologi Islam (JPI), 14(1), 121. https://doi.org/https://doi.org/10.18860/psi.v14i1.6498.

Negara, G. I., \& Dewi, R. S. (2019). Strategi dan Media Kehumasan Direktorat Jenderal Pajak (DJP) dalam Rangka Meningkatkan Kesadaran Perpajakan Lembaga Jasa Keuangan (LJK). Jurnal Ranah Komunikasi (JRK), 3(1), 45-54. https://doi.org/https://doi.org/10.25077/rk.3.1.45-54.2019.

Nugroho, M., \& Kusdarini, E. (2016). Strategi Pemerintah Desa dalam Meningkatkan Kesadaran Masyarakat dalam Membayar Pajak Bumi dan Bangunan. IPPK, 4(1), 117-128. https://doi.org/https://doi.org/10.17977/um019v4i1p117-127.

Pajakonline. (2020). Tingkat Kepatuhan Wajib Pajak Menurun Saat Pandemi Corona.

Permatasari, M., \& M, N. K. L. A. (2019). Pengaruh Kesadaran, Kualitas Pelayanan, Pengetahuan Perpajakan, Dan Sanksi Perpajakan Pada Kepatuhan Wajib Pajak Reklame. E-Jurnal Akuntansi, 28(1), 748 - 773. https://doi.org/https://doi.org/10.24843/EJA.2019.v28.i01.p29.

Pratama, W. P. P. (2016). Model Pembelajaran Karakter Pelaut. Jurnal Pendidikan Vokasi, 6(3), 318-334. https://doi.org/https://doi.org/10.21831/jpv.v6i3.11446.

Priyambodo, A. B. (2017). Implementasi Pendidikan Karakter Semangat Kebangsaan dan Cinta Tanah Air pada Sekolah Berlatar Belakang Islam di Kota Pasuruan. Jurnal Sains Psikologi, 6(1), 9-15. https://doi.org/http://dx.doi.org/10.17977/um023v6i12017p9-15.

Rosid, A. (2021). Nilai-nilai dalam Sastra Anak sebagai Sarana Pembentukan Karakter. Jurnal Pendidikan $\begin{array}{llll}\text { Bahasa Dan Sastra Indonesia } & \text { Metalingua, }\end{array}$ https://doi.org/https://doi.org/10.21107/metalingua.v6i1.10508.

Ruky, N. E., Putra, W. E., \& Mansur, F. (2018). Pengaruh Pemahaman Peraturan Perpajakan, Kesadaran Wajib Pajak, Akuntabilitas Pelayanan Publik dan Kewajiban Moral Terhadap Kepatuhan Wajib Pajak (Studi Empiris pada Kantor Bersama SAMSAT Kota Jambi). Jurnal Riset Akuntansi Dan Keuangan, 6(3), 405-418. https://doi.org/https://doi.org/10.17509/jrak.v6i3.14417.

Sugiyono. (2006). Metode Penelitian Kuantitatif dan Kualitatif dan R\&D. Alfabeta Bandung.

Suheli. (2018). Manajemen Peserta Didik Berbasis Pesantren dalam Pembentukan Karakter. Jurnal Kependidikan, 6(2), 207-221. https://doi.org/10.24090/jk.v6i2.2258.

Sujatmiko, I. N., Arifin, I., \& Sunandar, A. (2019). Penguatan Pendidikan Karakter di SD. Jurnal Pendidikan: Teori, Penelitian, Dan Pengembangan, 4(8), 1113-1119. 
https://doi.org/https://doi.org/10.17977/jptpp.v4i8.12684.

Sukirman, \& Minarwati. (2020). Pengaruh Pembelajaran Sastra Kreatif Berbasis Karakter Terhadap Pengembangan Karakter Siswa di Madrasah Aliyah Negeri Palopo. Jurnal Kependidikan (Didaktika), $9(4)$,

89-402. https://doi.org/https://jurnaldidaktika.org/contents/article/view/54/36.

Sukowidyanti, A. P., Nurlaily, F., \& Aini, E. K. (2019). Pengembangan dan Pelatihan Perpajakan Games Edukasi Perpajakan Untuk Meningkatkan Kesadaran Pajak Early Tax Payer. Jurnal Inovasi Hasil Pengabdian Masyarakat, 2(1), 18-30. https://doi.org/https://doi.org/10.33474/jipemas.v2i1.1637.

Supriatna, E. (2020). Wabah Corona Virus Disease (Covid 19) Dalam Pandangan Islam. SALAM: Jurnal Sosial Dan Budaya Syar-I, 7(6). https://doi.org/10.15408/sjsbs.v7i6.15247.

Vionita, \& Kristanto, S. B. (2018). Pengaruh Sosialisasi Perpajakan, Kesadaran Wajib Pajak,dan Adanya Sanksi Pajak terhadap Kepatuhan Perpajakan bagi Prospective Taxpayer. Jurnal Akuntansi Kontemporer (JAKO), 10(2), 81-91. https://doi.org/https://doi.org/10.33508/jako.v10i2.2217.

Yuliadi. (2018). Pengaruh Kesadaran Wajib Pajak dan Pelayanan Fiskus terhadap Kepatuhan Wajib Pajak Orang Pribadi Melalui Penerapan Sistem Administrasi Perpajakan. Jurnal Akuntansi Keuangan Dan Bisnis, 11(2), 57-66. 